\title{
The Role of Educators in Growing Leaders and Leadership
}

\section{Among School Students}

\author{
Abour H. Cherif, Ph.D. \\ Higher Education Consultant \\ Dean, Institute of Innovation, ACS Athens \\ acherif@aaua.org ; cherifa@acs.gr \\ Stefanos Gialamas, Ph.D. \\ President, ACS Athens \\ ACS Athens 15234 Halandri, Greece \\ gialamas@acs.gr \\ Peggy Pelonis, Ed.D. \\ Vice President, ACS Athens \\ ACS Athens 15234 Halandri, Greece \\ pelonisp@acs.gr \\ Jennifer Harris, Ph.D. \\ Faculty and Chair, Math Curriculum \\ DeVry University, Crystal City, U.S.A \\ jharris2@devry.edu \\ JoElla E. Siuda, Ph.D. \\ Lead Faculty - General Education \\ Northwestern College, Bridgeview, U.S.A \\ jsiuda@nc.edu
}

\begin{abstract}
Student activism has been a powerful force through the 20th century and continues into the 21 st century. Student protests now are more likely to be instigated by local events and one can see that when students are supported and encouraged, their leadership grows. This paper considers the role of educators in helping students develop their leadership abilities and skills through six examples: climate change protests started in Sweden, gun violence protests in schools sparked in the United States, protests highlighting refugee crisis in Greece, work to understand homeless individuals as human beings, protests focusing on the care for stray animals and movements to pay reparations to descendants of slaves in the United States. Each example is then viewed through the lens of what educators can learn from that experience so that they can most effectively encourage and help students in future movements.
\end{abstract}

Keywords: Student activism, Student's Leadership, Education Reform, Student's Engagement

DOI: $10.7176 / \mathrm{JEP} / 10-18-01$

Publication date:June $30^{\text {th }} 2019$

\section{Introduction:}

When school students are given opportunities to affect change in the world, they will do so. When circumstances and events affect their own lives, they step in and demonstrate not only inspired shared leadership, but also the power they inherently have to take action, to lead movements, to change things, and to alter the existing circumstances to support a better tomorrow.

Examples of student leadership and power have existed for decades. In the past, such as in the 1960s, protests encompassed students across the country. Students protested on many campuses against the Vietnam war as well as for civil rights. These were national and international issues led simultaneously nationwide. Today's student protests are often in reaction to a more local event, sparking the students in those areas to lead the push for change. 
These students then demonstrate the inherent power and leadership with which they are endowed. When opportunities open and encouragement is sustained, students' flourish as their leadership shines.

The more localized instigation of these protests creates an opportunity for local educators to encourage these students and nurture their leadership. Student leaders then demonstrate many of the qualities that education strives to instill in students every day. Educators can design and implement educational reforms that allow student leadership traits to flourish, whenever that opportunity arises. These educational reforms should be designed to encourage young student leaders to combat the effects left by bygone generations. High schools and universities can be a force behind the positive growth of their students, bringing these individuals with their vast knowledge and awareness of world events 'to the table'. Structures that encourage student leadership and power can serve to improve our world at an accelerated pace.

Six recent examples of student leadership are described in this paper. The first example involves school students' movement to shine a light on climate change in the world. The second example is the actions against gun violence and school shootings in the United States. The third example showcases students' reaction to the refugee crisis around the world. The fourth example involves student's movement and leadership involving an initiative to understand homeless individuals as human being like all of us. The fifth example involves elementary school students developing awareness and leading a cause to care for stray animals in urban cities. The sixth example involves undergraduate students at Georgetown University voting for a tuition increase for the purpose of paying reparations the descendants of enslaved people sold to pay the school's debt in the 1880's.

It is extremely important to note here, that these are but only six of the numerous acts instigated and brought to fruition by students, collectively and/or individually, as they seek to change the world in which they live. Whether in small rural or metropolitan areas, disregarding the status quo, these students rise to become leaders. Leadership is the mantle of power, and they chose to wield their power as they take on concerns that they have deemed crucial to the betterment of the world. What is the role of education and educators to encourage these leaders?

\section{Students' Movement in Support of, and Recognition of, World Climate Change:}

One powerful example of school students' power and leadership was seen in the 2019 school students' movement in support of recognition of world climate change. Thousands of students all over the globe followed the example of one young 16-year old Swedish climate activist, Greta Thunberg, who started and spearheaded the movement on August 18, 2018 by skipping school and standing in front of the Swedish parliament every Friday protesting climate change. On those Fridays, the young girl would hand out homemade fliers.

In the summer of 2018, this became a worldwide movement as students around the globe skipped school to protest and demand actions to combat climate change. On one day, the student protests occurred around the globe as students in at least 112 countries and 1700 locations protested at about the same time of day in their area; "starting in the South Pacific and moving west with the sun, the protests blanketed grand city centers and humble village squares" (Witte, et.al, 2019, ๆ.2).

On Friday, March 15, 2019, thousands of school students in more than 1,500 cities in more than 100 countries walked out of their classrooms to the streets, demonstrating their dissatisfaction with the views held by many of today's politicians. The student walk outs spoke volumes, as they hoped that politicians would be laying the framework for policy decisions that could reverse climate change. They voiced their disagreement with the viewpoint of some lawmakers that climate change does not exist; by walking out, they sent a clear message to particular policy makers that students perceive are not doing enough to reduce the level of climate change.

With determination, the students of this world put out a singular cry for recognition of this cause, and as well put the blame on those adults, policy makers, governments and organizations that were at fault. They used verbiage such as "the adults most responsible for the ravages of climate change," these adults "are going to be gone soon enough," "they are stealing our future," and "leaving us alone in the world." Therefore, as one student put it, "It is up to us, kids, to make a difference." At one location where students were assembled, a protest concerning government inaction on climate change ensued; students held signs stating "Stop the Fossil Fools" — a reflection of the contempt protesters [had] for the grown-ups who 'call[ed] the shots,' and who [were] widely seen as having reacted with complacency and caprice to the world's gravest threat” (\$. 7). In addition, on Friday, April 30, 2019, hundreds of students from many schools in New York City marched from the United Nation to the center of the 
city protesting the lack of real action to deal with the problem of climate change. Some of these students even went further, demanding that the city of New York declare a state of "Climate Emergency". As one 12 years old student clearly stated, it is our future, our life, and our Earth."

The good news that arose from these deliberate actions of students worldwide was that many countries and world leaders listened. Activists, as well as many national and international organizations including the United Nations, The European Union, African Union, etc., listened and promised to do something to ensure the sustainability of the planet and the future of the upcoming generation. However, while the movement received support and the attentions of many powerful leaders such as Chancellor Angela Merkel, a few politicians hit back with criticism such as Dan Tehan, the Australian Education Minister who was cited as saying that, "For action on issues that they (students) think is important, they should do that after school or on weekends."

In the end though, what transpired in this student-led undertaking was a realization that this is not the world of the 'adults only,' those considered to be 'wielders' of power. No, in fact, this was a strong, certain, blow to the status quo. Students found their 'voices', they assumed their positions of value and worth in this world. They recognized not only their abilities to lead and show their powerful positions as a voice in their respective communities, but more so, outside of their communities. They were the means to showcase that this is not a community set apart by itself; this is one of many communities, all inherently connected in a larger global society.

\subsection{Implications for Education:}

This example highlights how education must allow for inclusion of many viewpoints and create an inherently holistic curriculum. This calls into question the current separation of disciplines. In the case above, students needed to voice their ideas on global warming, and education should give them the strong underpinning that supports and broadens their knowledge of this scientific construct. Such study could incorporate science, technology, engineering, math, humanities, and history. Further, this concept points to the need for ethical training on how this construct of global warming affects businesses, energy policy, prices, employment, human health, species diversity of life forms, as well as the environment.

\section{Students' Movement Protesting Gun Violence and School Shootings:}

A second powerful example that shows both the power students have, and the type of the leadership they can demonstrate, is the students' movement protesting gun violence and school shootings in the United States. For example, after the school shooting that occurred on February 14, 2018 at Stoneman Douglas High School in Parkland, Florida, numerous anti-gun violence protests occurred widespread, with an emotional message of the imperative need for change; students 'for students' organized these protests all across the United States. Never Again MSD, an anti-gun violence organization formed by survivors of the Stoneman Douglas High School shooting, held their first rally in Fort Lauderdale, Florida on February $17^{\text {th }}$. This was attended by hundreds of students, all calling out for change, moving to a new order of things, a new perspective to be taken on guns in society here in the States. A 'lie-in' was organized outside the White House in Washington D.C. on February $19^{\text {th }}$ by a group of teenage school students. On February $20^{\text {th }}$, hundreds of students marched to Stoneman Douglas High School. An organized national school walkout occurred on March $14^{\text {th }}$, shortly followed by more protests throughout the U.S. by young adults.

The students from Parkland, Florida began encouraging companies who partner with the NRA - offering perks or discounts to members - to sever ties with the organization. Over a dozen companies dropped their NRA partnership in the days following. The event was called the 'March 1 NRA-sponsor boycotts'. (Held, 2019).

The power of students' voices, and their abilities to lead were demonstrated not only by those in the K-12 school level, but also by those at the collegiate level. In particular, students at the college level demonstrated the power of their voices, and assumed the necessary leadership characteristics to support fellow school students in their fight against school shootings and gun violence, etc., in their personal environments. For example,

Nearly 200 U.S. colleges added their names to \#Never Again Colleges, including the Massachusetts Institute of Technology (MIT), Harvard University, Yale University, Columbia University, and the University of Florida, to name a few. The colleges would not penalize high school students who faced disciplinary action as a result of participating in a peaceful Never Again MSD protest. (Held, 2019). 
These students' actions forced national debates and discussions, ones that were duly needed. This led to many prominent NRA-sponsors to boycott the NRA. This as well led to some individual NRA members to decide to drop out of the organization after the massive uproar in social media. Even numerous cities, counties, and states sought to make changes to their existing gun laws. This even contributed to a number of elected officials losing their political positions, as newly elected officials up seated them in various political positions at the city, county, state, and national levels of office. The most important 'takeaway' in all of this, was the broad public awareness and attention given to this crucial cause in the eyes of these divergent student populations.

Again, as in the previous example, here was a means whereby students' made their voices known. They are inhabitants of a world of media and mass marketing. Propelled by knowledge of how these two entities can sway perspectives, they capitalized on both, even if unknowingly. Media could translate their feelings and emotions about guns and gun violence into news clips and podcasts that would be seen worldwide. Media gave them a captive audience to showcase their internal struggles of attempting to understand the atrocities of gun violence. And with this, came the concomitant attachment of 'goods to a cause'. As it was made clear that guns were viewed as harbingers of destruction, those that were deemed linked to this destruction were marginalized. The NRA was being viewed as 'co-conspirators' by some of these students, as they did not recognize the troubles with guns and gun violence. As this backlash moved forward, the NRA saw the loss of their supporting sponsors. This was a crucial point for students undertaking leadership positions. They knew their voices could not only be heard, but take on the financial markets; perhaps unwittingly, or otherwise, they knew that their words of making it safe for all could as well bring in a financial component that could 'open the ears' of others.

\subsection{Implications for Education:}

Here in the educational arena, this example emphasizes the importance of education and listening. Gun violence involves people, and the taking of life, while for others, it is a family activity of hunting or a sport of skill. Students of today cannot live in a place where they do not listen to the view and feelings of others from all sides, recognizing the pain and suffering of those affected by gun violence and at the same time, understanding the comradery and traditions of others. Thus, education can encompass the skill of listening, and make sure they are empathetic and caring to others around them. This is what great leaders do, and this is where an educational system can nourish young student leaders.

4. Students' Movement and Leadership Involving the Recent Refugee Crises in Our Global World: Recently, our world has witnessed a refugee crisis as it has been estimated that more than 68 million people around the world are displaced from their own homes, thereby leaving behind their unique life experiences and dreams for a better future for themselves, their children, and grandchildren.

More than a third of the world's displaced population - some 25.4 million people - have been forced to flee their own countries entirely, leaving familiar lands behind. Over two-thirds of those refugees come from just five countries: Syria, Afghanistan, South Sudan, Myanmar and Somalia. (Mercy Corps, 2019, II. 5).

About 6.3 million refugees were from Syria alone; this has been considered to be one of the largest forcibly displaced populations in the world. This crisis is one of the greatest threats to that population.

After war erupted in March 2011, it took two years for 1 million people to be displaced. Another million were displaced within six months. Now seven years on, more than half of the pre-war population has been internally displaced, or forced to seek safety in neighboring countries. That's more than 11 million people on the run, including some 6.3 million people who have escaped across the borders. (Mercy Corps, 2019, II. 8).

The crisis captured the attention of many people across the world -- students, organizations, foundations, governments, and activists, etc. reacted world-wide. One example is the response of the students of the American Community Schools of Athens, ACS-Athens. Driven by the severity of the situation as seen in the news and other avenues of social media, students at the ACS-Athens felt a strong desire to show their degree of care for humanity and human beings; they exercised their power and leadership skills as they took the initiative for organizing campaigns to collect and distribute donations to the refugee people. After a while, ACS-Athens students 
realized that their power, energy and effort could be better served. What they felt they needed to do was to focus on the refugee minors who were not attending school. The goal of the ACS-Athens students was to support a change in thinking of the refugee youth, as they touted the notion that one must learn regardless of their circumstances. These students approached their school teachers, administrators, and academic leaders to work with them to do something that could make a difference in the lives of those young unattended refugee minors.

Demonstrating leadership capacity, students led the effort in the creation of the Youth-to-Youth program. This program was designed for these young unattended refugee minors, as a means to get them into some form of education while their status was being reviewed. ACS-Athens students collected donations such as school supplies, while also talking with media and community leaders, asking for their support by being a part of this urgent and crucial matter. Their efforts were 'payed back' beyond measure. The Youth-to-Youth program, started initially as a volunteer program where students helped teach refugee kids as needed, became a consistent, scheduled event. One day of the week, Saturdays, volunteering students, faculty, administrators, and parents came together to teach Greek, English, music, and sports to the refugee minors. In the same breath, they were providing a place of safety and belonging for these unaccompanied children. This program on Saturdays evolved into a 'full forward moving' operation.

As the second year came about, refugee students had yet an even bigger support system put into place. Those who achieved a certain level of academic and educational readiness, and demonstrated inner confidence, were allowed to join the ACS-Athens school program. Because of this success, the Shapiro Foundation based in the United States has provided eighteen of these students full scholarships to attend ACS-Athens as full-time students. The success of the Youth-to-Youth program, which started as a group of students in ACS-Athens wanting to show their love for humanity, became even bigger; by exercising their power as a community, and showcasing their leadership abilities, they captured the attention of the world. Media, government officials, organization, foundations, activists, and even the European Union, looked at this program as a potential for a new model for schooling and educating displaced young populations.

\subsection{Implications for Education:}

Here, students created education for other youth. They created this education based on the needs of those in need, regardless of the paradigms of education. It was truly the students that saw a need, and worked forward to satisfy that need for fellow youth. They 'listened' to the voices of their peers, and developed a curriculum that fostered support in these particular times. Their 'school' hinged on the needs of these students, and these students alone, not ascribing to a 'cookie cutter' school model. The educators and administrators that joined them demonstrated how sometimes students lead and adults must follow. The students who created the education learned from those adults how to be a follower and how to grow an idea based on expanding insights. This model not only ushered in a new educational paradigm, the school with its students, faculty, administrators and academic leaders has worked collectively to demonstrate what Linda Lambert (1997) has termed 'leadership as learning' processes among participants in a community - processes that lead toward a shared sense of vision and intentional purpose. This example points to how education needs to be open to where students lead. Here was a paradigm shift in education, notably and completely an inception of the youth.

\section{Student's Movement and Leadership Involving an Initiative to Understand the Issue of Homelessness:}

An ACS Athens student in her Junior year founded a movement called KOINWNOSn (pronounced KINONOS)

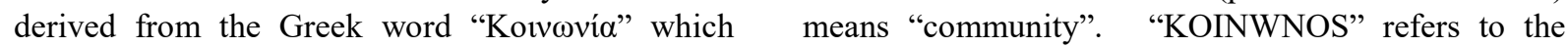
community of people that come together with a common cause. It connotes the importance of participation in community affairs; that we must all participate in order to have a healthy, thriving community. On a larger scale "KOINWNOS" denotes that we are all part of a community with many differences and commonalities, the main commonality being that we are all human beings. She and seventy of her peers that joined the cause wanted to know more about the 'homeless' people in Athens. They wanted to get to know them in order to understand their challenges and know their stories. They wanted to interact with them so that they could become real human beings rather than faceless problems on the streets of Athens.

The students desire to create this movement came about from the notion that 'belonging', 'community feeling' and 'social interest' are necessary elements in order for people to be participating members of a community. The student was cautioned by the adults in the school about the dangers this could entail. She however decided to pursue it, knowing that failure could be just around the corner, because of a deep desire to understand this population better. 
She was aware that according to the United Nations survey in 2005, 100 million people are homeless worldwide. In Greece, the government estimates about 20,000 without homes.

Other organizations distributed food and clothes to the people on the streets daily. The ACS Athens students joined one such organization and made it a point to go to down town Athens to help with the distributions weekly from 10:00 pm to 2:00 a.m. They fundraised and created their own food and clothes drives. Most importantly however, they interacted with the people on the streets, having conversations, telling jokes, greeting one another once the students became familiar and friendly. Did they provide a little sense of dignity by looking them in the eyes and spending some time with them? The people on the streets told the students exactly this. For the ACS students it was a life changing experience.

As a result and as part of the efforts to raise awareness, ACS students were invited to speak with students from Think Global School, who joined their efforts on the streets during their stay in Athens. Furthermore, a second invitation was extended from a group of post graduate psychology students. These were adults, intrigued by the story and by the determination to contribute to this cause. Some said that the students managed to eliminate the fear they felt toward the 'homeless' because if "young people could interact and help, we will certainly contribute".

Most of the students, teachers and parents that joined the street work went with hesitation and a bit of fear. Yet, in the days that passed, more than 70 students and 30 adults came to see the humane part of all those there. They got a close look at a social problem that needed a solution. The people on the street expressed gratitude that they were met on an equal level and communicated to with respect. Sometimes, they said, "this is more important than food and clothes".

\subsection{Implications for Education:}

Sometimes adult hesitation can stifle natural learning. Giving voice and opportunity to students to "grow" their interests and allow their ideas to evolve is a necessary part of the school curriculum. Education including disciplines such as Mathematics, English and Science is indeed necessary to develop individuals with skills and knowledge prepared to succeed in a competitive society. Yet, growing conscious citizens who are prepared to lead causes that will make the world a better place should be part of every school curriculum. While there will always be room for improvement in the world related to issues of equality, poverty, environmental care and educational opportunities for all, growing student leaders that are conscious citizens can help create a critical mass of people who are part of the solution and as such tip the balance toward alleviating the above said issues.

\section{Elementary School Students Developing Awareness and Leading a Cause to Care for Stray Animals in Urban Setting:}

Elementary School students at ACS Athens know that they live in a country full of stray animals that are in desperate need of food, medicine, and homes. A group of these students reached out to numerous animal shelters who voluntarily work day and night to provide these animals with shelter, love, and a better quality of life. One of these is the Animal Welfare Union of Pikermi (and Mati), Pigasus, who less than a year ago treated many of the wounded stray animals, victims of the recent horrific fires in Mati and Neos Vountzas in Greece. The ST.A.R.T Club (Stray Animal Rescue Team) has taken action, and chose to help this animal shelter through the end of this school year. Fundraising efforts and volunteer activities to take care of the dogs have been put in place by students themselves, teaching one another responsibility, empathy, and taking care of the four legged creatures that are incapable of caring for themselves.

\subsection{Implications for Education:}

Opportunities for voluntary activity involving students eager to provide community service should be encouraged in every school. Children learn to respect and care for animals while developing empathy, responsible behavior and can experience intrinsic satisfaction as a result of their contributions. Self-esteem can also be enhanced as students experience the results of their contributions and feelings of belonging, and being capable can go a long way in further developing awareness of such social conditions.

\section{University Undergraduate Students Voting to Rise Tuition for the Establishment of a Fund Benefiting the Descendants of Enslaved People Sold to Pay off the School's Debts in the 1880s:}


On Thursday, April 11, 2019, students at Georgetown University in the USA voted to raise tuition at the school by $\$ 27.20$ per semester to provide reparations to the descendants of 272 slaves owned and later sold by the school in the 1800s. Even though it is a nonbinding referendum, the voting and its results demonstrated both students' awareness and moral understanding of the consequences of what Jesuits who ran the Georgetown University did in 1838 as well as students' leadership and collective power in achieving desirable outcomes. To provide justice, and to send a clear message that inhumane actions took place at the sole discretion of Georgetown University, a 'call to action' was set forward. Students instigated and supported a measure to ensure that descendants of the 272 enslaved Africans who were sold in 1838 by the school as a means to keeping it solvent should be compensated. Furthermore, the association recommends "the fund be enacted in fall 2020 , with annual adjustments for inflation. The money would be controlled by a new committee comprised of five descendants of those 272 slaves and five undergraduate students and will cover the descendants, both on campus and across the USA" (Oliviera, 2019, II. 7).

What is interesting about the action that the undergraduate students of Georgetown University took is that instead of asking the university to take responsibility and compensate the descendants of those 272 slaves owned and later sold by the school, the students assumed the role of the leadership in taking the responsibility and the willingness to pay higher tuition in order to create a slavery reparations fund. It is important however to state that Georgetown University "has formally apologized for its role in the slave trade and renamed buildings on campus for the formerly enslaved. Furthermore, the school has agreed in 2016 to give admissions preference to descendants of the 272 slaves" (Oliviera, 2019, 9,7 ). It is also important to mention that there were some students in the university who did not vote or support the action, but by the power of voting and the process of democracy, the vote for raising the tuition passed by the majority of students.

The second institution brought into light for possible links to the slave trades or related matters is Oxford University. In 2016, the students at Oxford started a movement trying to remove the statue of the colonist Cecil Rhodes, as he promoted slavery and the ideology of White Race Supremacy during the Colonia era. At that time, they did not succeed, but still consideration has been given for the removal of the Rhodes statue (Coughlan, 2015). The students' campaign to remove the Cecil Rhodes statue from Oxford followed a university protest in South Africa where the "status of Cecil Rhodes was attacked and then ultimately taken down at the University of Cape Town, after [it]being identified by protesters as a symbol of a Colonial, pre-Apartheid era. Rhodes had been a strong advocate of Colonial power in Africa" (Coughlan, 2015; 2019).

While the cause of the initial start was different, Georgetown University is not alone in this awaking moral awareness to its past. For example, because of coming under increasing pressure to investigate and to acknowledge any connections to slavery, a number of other colleges and universities in the UK and US have started inquires to their own history. For example, in September 2018 "the University of Glasgow, Scotland, published its own report into its links with racial slavery, which found that it had received significant financial support from people involved in the slave trade" (Guy, 2019, ๆ., 10). As a result of this, Glasgow University said it would launch a "program of reparative justice" after discovering it gained up to 200 million pounds (\$260 million) in today's money from historical slavery" (Reuters, 2019, ๆ., 13). In 2017, Harvard University "hosted a national academic conference to explore the historical role of US colleges in propagating slavery" (Guy, 2019, ๆ. 11). One more example comes from Yale University. In 2017, Yale "renamed its Calhoun College after protesters said the Ivy League school should drop the honor it gave to an alumnus who was a prominent advocate of U.S. slavery. It is now called Grace Hopper College after the computer scientist” (Reuters, 2019, ๆ., 11).

Furthermore, extremely crucial to the points made above about Georgetown University and University of Oxford, other premier universities have come into the news in their struggle. One of these universities which is trying to grasp the past, trying to find the correct 'lens' on how to 'view' these past activities is Cambridge University. However, with that noted, as Cambridge University was working on finding a deeper understanding, the administration nevertheless set up a committee to come to some consensus on what occurred, and what steps need to be taken next (NBS 2019). For example, in an announcement by Cambridge University, was noted on April $30^{\text {th }}$ 2019 of a possible link of the university to the slave trade. Professor Stephen J. Toope, vice-chancellor at the University of Cambridge, wrote in the release that "There is growing public and academic interest in the links between the older British universities and the slave trade, and it is only right that Cambridge should look into its own exposure to the profits of coerced labor during the colonial period," (Guy, 2019, ๆ. 3). 
Cambridge says the study is part of a "wider reflection" on the links between slavery and universities in Britain and the U.S. Vice Chancellor Stephen Toope said the university has an obligation to look into how it might have profited from forced labor during the colonial era. (The Associated Press, 2019, II. 5.)

Because of this, the university selected and appointed Martin Millett, a Laurence Professor of Classical Archaeology to be the chairman of an eight-member committee to see if there is any wrongdoing on the part of the university in this link to the slave trade matter. Millett stated that "it [is] unclear what the investigation might turn up, but that it was reasonable to assume that Cambridge had benefited from the slave trade." (Reuters, 2019, ๆ. 5).

As well comes yet another tangential thought, is this something that the administrations for these universities to rectify? One would assume so, but this was not the case with Georgetown University. The students took the situation into their own hands, as they supported a tuition increase. One could ask if it is appropriate that students 'pay' for the transgressions of the school.

\subsection{Implications for Education:}

The students at Georgetown University took up this cause based on their understanding of the history of the university and their awareness of shared humanity worldwide. In working to pass the resolution, student leaders needed to convey the injustices that needed to be corrected. Education can help groom these voices to be efficient in the telling of the story and well as the ethical component must underlies that story. This is teaching the essentials of communication in a manner to help students achieve their stated goals.

Further, education should allow student voices to be heard, and explore rationales for why these are the thoughts and ideas they have. Education can encourage students to act in order to preserve justice or correct injustice. As educators listen, they must be open to the idea that they are situating their ideas/thoughts on many differing levels, with numerous possible contexts. Educators perhaps need to note a more 'worldly' view of education as students do. If they are engaged in contemporary issues of unfairness today, they will look back into the past for disenfranchisement in the past of others. Education can help students be leaders of today that recognize the wrongs of yesterday; then, make that difference, and change the tides for a better tomorrow (Cherif, Gialamas, and Ofori-Amoah, 2000).

\section{Final Remarks:}

The challenge for existing educational systems is how to recognize the inherently innate power and leadership traits that school students possess. And then, they must ask themselves, how do they work to alter the existing educational and schooling philosophies, policies, and practices in place now? In our existing school systems, there is a need to nurture the learning leadership processes, to empower students, to educate them to build a new mindset so they can confidently articulate their own learning and support their unique personal futures. Current students are already starting the paradigm shift in education, but it is now in the hands of educators to ensure the completion of the paradigm shift by conceiving of a better order of things, a more inclusive educational experience.

The six examples presented here point toward educational structures that encourage a more wholistic education structure, foster more mutual listening across different perspectives, demonstrate a willingness to follow student leaders, and enlighten students on nuances of effective persuasive communication guided by ethos (doing the right things when no once watching).

Adding to this unique challenge is the fact that while it is true that learners vary greatly in as far as experience, socioeconomic status, culture, ethnicity, learning styles and cognitive ability are concerned, they still collectively, as well as individually, possess inherently innate power and potential leadership traits. But in reality, while this might be a challenge, it is not a problem. Indeed, it is a positive factor in forcing educators and policy makers to be creative and to look and think 'outside the box' when they make educational decisions, and curriculum choices for students. This is simply because such diverse learners "bring their own learning and personal character to the classroom, which influence the classroom atmosphere, time management, content to be taught and the educator's teaching style" (Celik, 2019, p. 31). Therefore, academic leaders, educators and policy makers are forced to think of generating and applying different types of instructional methods to meet all the learners' needs and improve their strength; this is needed so as to see the natural diversity in the classroom as an asset for inclusion and power building, instead of preventing any learner from achieving the instructional goals in question. 
These differences even further highlight the need for the changes in structure suggested through the six strong examples of student leadership. A more wholistic education structure can encompass more individuals with their experiences and students learn to see events and circumstances from a variety of views. When discussing these differences, faculty are encouraged to foster more listening across different perspectives. The respect for different perspectives must go both ways, from those starting the movement to those who oppose the movements. By understanding both sides, more progress can be made. Throughout the exchange of ideas and perspectives, educators can determine if they have a role in that particular movement as a follower to the student leaders. These times and places must be judiciously determined. Finally, education can specifically be designed to enlighten students on nuances of effective persuasive communication. Communication is not hollering or demanding that others agree with your perspective because you are loud or have the largest sign. The power of humor, empathy, and finding some common ground can play huge roles in forwarding a movement.

In short, when students' power and potential leadership traits are recognized, trusted, and nurtured when they are given the opportunities to exercise these two inherently innate traits, and when students are provided differentiated instruction that meets their needs, a 'tipping point' can be reached. It is at this precise moment that a positive learning environment ensues. This creative moment will then establish a new paradigm, one which will enable and empower students (individually and collectively) to transform not only their own world, but the whole world as architects of their own learning, and in turn their own world's reality (Gialamas, 2019).

Curriculum reform and educational philosophy should deem as high priority the recognition of school students' innate power to lead and have ownership of their power. Clearly, recognition is demonstrated for this needed paradigm shift in education as shown in these six contemporary issues. With the examples shown here of gun violence, climate change, global refuges, understanding homelessness as human beings, caring for stray animals in urban cities, and reparations for past wrongs against a demographic group, it is clear that students want change. With this change, they are not only willing to lead, but want to lead, as they 'see' that the status quo of leaders may not be enough to instigate solutions.

As these changes to education and curriculum are considered, schools might also want to consider ethical or moral determinations to guide these efforts. The examples noted here would be considered movements that promote positive change by a likely majority of students and educations. However, other movements will not be as popular or have such broad support. The students leading these other movements are likely to feel just as strongly about their cause and still demonstrate amazing leadership skills, drive, and determination. As changes are considered, educators should also consider their role in these less popular movements. For example, can faculty maintain a respectful discussion when a vast majority of the class disagrees with the movement being proposed. Certainly, respectful communication is required in all situations. Educators might be less likely to join student movements as followers of the student leaders if they disagree with the objectives of the movement. Will the school allow those types of choices, or are the benefits of student leaders having educators as followers sufficient to have that occur in all movements? Finally, when teaching and developing more impactful communications, can student leaders work toward a more effective communication of a concept the instructor and perhaps the school disagree? Part of ethical education is in demonstrating how the school will handle movements that go against their morals.

After all, as Linda Lambert (1998) wrote in her book "Building Leadership Capacity in Schools", schools today involve more than a single leader. She defines leadership as the learning processes that lead toward a shared sense of vision and purpose. She explained leadership capacity as the breadth of participation in leadership and the depth of skill that teachers, administrators, parents, students, and community members bring to the work.

While it is agreed, the students go to school to learn, learning involves many things, and takes place within and beyond the classrooms and school environment. Student leadership also comes in a variety of forms. Schools can support the many types of leaders possible--- student learning leaders, student teaching leaders, student councilor leaders, student sport leaders, student community activist leaders, student media and communication leaders, student coach leaders, to name a few. What helps students to exercise and demonstrate their leadership is their ability to think critically, work collaboratively, participate informatively, and behave ethically. Moreover, these students need to learn how to substantiate their ideas, views, and vision with evidence, and to continually evaluate and assess their own work. They must ensure to look at this task as crucial to their personal development, as well as always being mindful to lead and support others. As they lead by example, they must foster these same tenets 
in their peers, building one another's learning, and thereby, building a community of leaders. Educators can help them attain these characteristics, through a strong, positive example. After all, as advocated by the belief that a growth mindset, intelligence, ability, and behaviors are malleable and can be developed (Mindset Works, 2019), leadership is no exception. The challenge for educators and educational systems is how to develop, practice, and reinforce student leadership through formal education for the 21 st century.

\section{References}

The Associated Press (2019). UK's Cambridge University to Investigate Slavery Links. The New York Time, April 30, 2019. https:/www.nytimes.com/aponline/2019/04/30/world/europe/ap-eu-britain-slavery.html

Chase, Howard, and Tabassum, Faria (2018). What Is Decolonisation and Why Does It Matter at Cambridge? VARSITY, Friday September 28 2018, 12:05pm. https://www.varsity.co.uk/features/16143

Celik, Suleyman (2019). Can Differentiated Instruction Create an Inclusive Classroom with Diverse Learners in an Elementary School Setting? Journal of Education and Practice, Vol.10, No.6, 2019, pp. 31-40. ISSN 2222-1735 (Paper) ISSN 2222-288X (Online) DOI: 10.7176/JEP. https://www.iiste.org/Journals/index.php/JEP/article/view/46684/48204

Cherif, A., S. Gialamas, and B. Ofori-Amoah (2000). Can Human Factor be Taught in the Classroom. Review of Human Factor Studies Journal, 5(1\&2):89-114.

Coughlan, Sean (2019). Cambridge Investigates Its Slavery Links. BBC News, 30 April 2019. https://www.bbc.com/news/education-48097051

Coughlan, Sean (2015). Oxford College Considers Removing Rhodes Statue. BBC News, 17 December 2015. https://www.bbc.com/news/education-35123199

Gialamas, S. (2019). The Students of the $21^{\text {st }}$ Century Transform the World. The Economist, p. 183-184.

Guy, Jack (2019). University of Cambridge to look into how it benefited from slavery. CNN, Updated 5:14 AM ET, Tue April 30, 2019. https:/www.cnn.com/2019/04/30/uk/cambridge-university-slavery-study-scliintl/index.html

Hassan, Adeel. (2019). Georgetown Students Agree to Create Reparations Fund. The New York Times, April 12 , 2019. https://www.nytimes.com/2019/04/12/us/georgetown-reparations.html

Held, Amy (2019). One By One, Companies Cut Ties With The NRA. National Public Radio (NPR), February 23, 20183:24 PM ET. https://www.npr.org/sections/thetwo-way/2018/02/23/588233273/one-by-onecompanies-cut-ties-with-nra

Hess, Abigail (2019). Georgetown students vote to raise tuition by $\$ 27$ per semester to pay slavery reparations. CNBC Make it, Fri, Apr 12 2019. https://www.cnbc.com/2019/04/12/georgetown-votes-to-raise-tuitionby-27-to-pay-for-reparations.html.

Lambert, Linda (1998). Building Leadership Capacity In Schools. Alexandria, Virginia: Association for Supervision and Curriculum Development (ASCD).

Maharjan, Namita, et.al (2019). Generic Skills Assessment Through Implementation of Group Based Learning to Understand SDGs. Journal of Education and Practice, Vol.1No.6, 2019, pp. 14-23. ISSN 2222-1735 (Paper) ISSN 2222-288X (Online) DOI: 10.7176/JEP https://www.iiste.org/Journals/index.php/JEP/article/view/46682/48202 .

Mercy Corps (2019). The world's 5 biggest refugee crises. Mercy Corps, https://www.mercycorps.org/articles/worlds-5-biggest-refugee-crises

Mindset Works, Inc. (2019). Growth Mindset \& SEL Cuture-Building. Growth Mindset: SEL \& Academic Learning Catalyst edWebinar Hosted by Mindset Works ${ }^{\circledR}$. https://s3-us-west-1.amazonaws.com/mindsetnet-site/FileCenter/Mindset-Works-Playbook.pdf

NBS News (2019). Cambridge to study how it profited from Atlantics slave trade: The research will examine specific gifts, bequests and historical connections with the slave trade. https://www.nbcnews.com/news/nbcblk/cambridge-study-how-it-profited-atlantic-slave-trade-n1000011

Oliviera, Nelson (2019). Georgetown University students vote to raise tuition to create slavery reparations fund. Chicago Tribune, April 13, 2019. https://www.chicagotribune.com/news/nationworld/ct-georgetownslavery-reparations-fund-20190413-story.html .

Reuters (2019). Cambridge to study how it profited from Atlantic slave trade. Reuters, April 30, 2019, 8:14 AM CDT. https://www.nbcnews.com/news/nbcblk/cambridge-study-how-it-profited-atlantic-slave-traden1000011

Wikipedia (2018). 2018 United States gun violence protests. Wikipedia, the free encyclopaedia. https://en.wikipedia.org/wiki/2018_United_States_gun_violence_protests

Witte, G., Beck, L., Dennis, B., and Kaplan, S. (2019). Thousands of students demonstrate in Lausanne, 
Journal of Education and Practice

Switzerland, as part of the global climate strikes on Friday. Washington Post, March 15 at 12:11 PM. https://www.washingtonpost.com/world/school-climate-strikes-draw-thousands-to-the-streets-in-citiesacross-the-globe/2019/03/15/ad365672-402d-11e9-85ad-

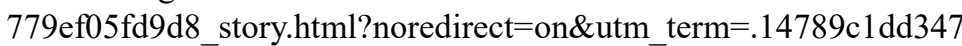

